\title{
Determining the landscape priority and their threats for the Critically Endangered Pongo tapanuliensis population in Indonesia
}

\author{
DEDE AULIA RAHMAN ${ }^{1,2, \boldsymbol{\varphi}}$, DONES RINALDI ${ }^{1,2}$, WANDA KUSWANDA ${ }^{3}$, RONDANG SIREGAR $^{4}$, \\ FITRI NOOR CH ${ }^{5}$, FAHMI HAKIM ${ }^{2}$, HARNIOS ARIEF ${ }^{1,2}$, HARYANTO R. PUTRO $^{1,2}$ \\ ${ }^{1}$ Department of Forest Resources Conservation and Ecotourism, Faculty of Forestry, Institut Pertanian Bogor. Jl. Lingkar Akademik, Kampus IPB \\ Dramaga, Bogor 16680, West Java, Indonesia. Tel.: +62-251-8621677, `email: dede.auliarahman@gmail.com; pokjabatangtoru@gmail.com \\ ${ }^{2}$ Working Group of Sustainable Management of Batang Toru Landscape, Faculty of Forestry, Institut Pertanian Bogor. Jl. Lingkar Akademik, Kampus \\ IPB Dramaga, Bogor 16680, West Java, Indonesia \\ ${ }^{3}$ Aek Nauli Environmental and Forestry Research and Development Institute, Ministry of Environmental and Forestry. Simalungun 21174, North \\ Sumatra, Indonesia \\ ${ }^{4}$ Daemeter Consulting. Bogor 16128, West Java, Indonesia \\ ${ }^{5}$ Center for Conservation of Natural Resources of North Sumatra, Ministry of Environmental and Forestry. Jl. Sisingamangaraja Km. 5,5 No. 14, \\ Marindal, Medan 20217, North Sumatra, Indonesia
}

Manuscript received: 5 October 2019. Revision accepted: 17 November 2019.

\begin{abstract}
Rahman DE, Rinaldi D, Kuswanda W, Siregar R, Noor CF, Hakim F, Arief H, Putro HR. 2019. Determining the landscape priority and their threats for the Critically Endangered Pongo tapanuliensis population in Indonesia. Biodiversitas 20: $3584-3592$. Understanding the habitat preference and spatial distribution for the management of medium-large primates is important for conserving and enhancing biodiversity in the most isolated and remote Batang Toru landscape, North Sumatra, Indonesia. Based on the first extensive orangutan survey dataset during 2000 and 2007, we aimed to provide microhabitat preference and distribution assessment for the new species of orangutan (Pongo tapanuliensis), a poorly known and threatened primate endemic in Indonesia. To inform future conservation measures, we develop a predictive habitat suitability map and use this map to show the current threat for Tapanuli orangutan in their habitat and as the basis of proposed of the landscape boundary in Batang Toru ecosystem. In order to identify some environmental factors affecting conservation, we analyzed the microhabitat preference of Tapanuli orangutan using maximum entropy modeling (MaxEnt). The modeled orangutan distribution map covers 1.458,06 $\mathrm{km}^{2}$ (58,52\% of Batang Toru's landscape) and reveals three distinct distribution areas. The four most important environmental predictors are the distance from the cultivation area, NDVI, mean precipitation, and distance from the secondary forest edge. The distribution of the orangutan overlap with land-use categories reveals that $42,98 \%$ of the distribution lies in protected areas, but that $15,54 \%$ lies in natural forest concessions and area for other purposes (APL). Large scale land-use masterplan is needed to provide strategies and control for future development in the possibility of land uses and management are allowed in the landscape including its conservation policies. Moreover, collaborative management strategies are needed to develop a sustainable management system. We confirmed the Batang Toru landscape as the sole of Indon esia's biodiversity hotspots and a critical area to preserve the Tapanuli orangutan.
\end{abstract}

Keywords: Primate, conservation planning, landscapes approach, species distribution model

Abbreviations: asl: above sea level,AUC: Area Under the Curve,IUCN: International Union for Conservation of Nature and Natural Resources,MaxEnt: Maximum Entropy,NDVI: Normalized Difference Vegetation Index,Pas: Protected Areas,ROC: Receiver Operating Characteristic,SLA: Sustainable Landscape Approach,WGSM-BTL: Working Group of Sustainable Management of Batang Toru Landscape

\section{INTRODUCTION}

The Tapanuli orangutan, Pongo tapanuliensis, is the smallest population number of orangutan species (Kuswanda 2014; Wich et al. 2016) and considered to be evolutionarily distinct from its closest relatives in the Borneo lowlands (Nater et al. 2017). It is reported to range over a small area restricted to Landscape priority for Pongo tapanuliensis the three main forest blocks (Wich et al. 2016). The Tapanuli orangutan is a key species for conservation, plays its ecological role as a seed disperser and its complex history of co-evolution and adaptation to a remote area of the Batang Toru ecosystem, North Sumatra, Indonesia (Fredriksson and Usher 2017). Tapanuli orangutan is the most isolated primate in the world and categorized as Critically Endangered on the IUCN Red List (Nowak et al. 2017). The main threats to populations in the Batang Toru ecosystem are related to habitat loss, fragmentation, and hunting pressure (Kuswanda 2014). Since the presence of the orangutans in the Batang Toru ecosystem was only discovered at the ends of the 1990s (Fredriksson and Usher 2017), little is know about the reliable information on distribution and its potential response to future habitat change scenarios have not been wellevaluated. Reliable information on the range and condition of habitat, are essential to the management of conservation of species (Rahman et al. 2018; Rahman et al. 2019).

In several decades, some approach showed that the success of long-term conservation of species requires the interventions to include entire landscapes since designated 
protected areas (PAs) are often not complete ecological units (Tallis et al. 2008; Dutta et al. 2016; Kashwan 2016). Moreover, the conservation of a single species based on ecology has become a populist and expedient approach to priority landscape conservation. Ecologically, the concept of umbrella species is at the root of the ideas in this approach, where one species selected for making conservation-related decisions, typically because protecting single species indirectly protects the many other species that make up the ecological community of its habitat (Runge et al. 2019). In the early 2000s saw increasing of suggestions and criteria for choosing such 'umbrella' species (Fleishman et al. 2000; Seddon and Leech 2008) based on biological traits such as distribution, habitat use, mobility, and sensitivity to disturbance as well as logistical considerations such as data availability, policy mandates, and funding availability. But, the evidence shows it is not entirely true that using the presence or abundance of a single species to select sites for conservation action will provide ecological protection for all species and their ecological processes (Seddon and Leech 2008; Branton and Richardson 2011; Runge et al. 2019). The World Heritage Convention (1972) recommended conservation actions of the species at the scale of landscapes. A complete landscape approach is needed that accommodates the physical condition of the ecosystem and socio-economic and cultural needs of the surrounding community and strong political support (Conservation International 2008) in the context of conservation of the Tapanuli orangutan as an 'umbrella' species in the Batang Toru ecosystem.

In understanding the ecological and biogeographic characteristics and their implications for the existence of a species, long-term historical data are needed that will offer a complete insight into understanding these characters. Moreover, long-term historical data can also help develop predictive power for the conservation management of species (Chapron et al. 2014; Turvey et al. 2015). In recent years, a number of reliable methods such as Maximum Entropy Modeling (MaxEnt) have been developed to predict distributional areas and classifying landscape suitability for species based on the correlation of presence records and environmental variables (Phillips et al. 2006). The use of this methodology has literally increased in recent years (e.g., Yi et al. 2016; Rahman et al. 2018), thereby improving our knowledge of species distribution and mapping the possibility of threats in current and future (Rahman et al. 2017).

This research was conducted to provide the Tapanuli orangutan distribution across the Batang Toru ecosystem by using MaxEnt modeling. Moreover, using the distribution of Tapanuli orangutan and locality of Batang Toru characteristics, we map landscape needs for the management of the Batang Toru ecosystem.

\section{MATERIALS AND METHODS}

\section{Study area}

We studied Pongo tapanuliensis in the Batang Toru ecosystem, an isolated forest area in North Sumatra,
Indonesia ( $\left.1^{\circ} 25^{\prime} 52^{\prime \prime} \mathrm{N}-98^{\circ} 46^{\prime} 56^{\prime \prime} \mathrm{E}\right)$. Batang Toru forest is the last refuges for the new species of orangutan, the Tapanuli orangutan. According to the classification of Schmidt and Ferguson (1951), the Batang Toru ecosystem climate is categorized in type Af (Köppen Climate System; Volken and Brönnimann 2011). Within the landscape mean temperature varies between $17^{\circ} \mathrm{C}$ and $27^{\circ} \mathrm{C}$, and relative humidity ranges between $79 \%$ and $90 \%$ (www.bmkg.go.id). The mean annual rainfall reaches 2100 to $3610 \mathrm{~mm}$ on the southern coast; rainfall is more abundant during the north-west monsoon from the end of October until April (wet season) than during the south-east monsoon from May to October (dry season). The Batang Toru ecosystem is characterized by a steep topography (with terrain slopes $>60^{\circ}$ ) and a wide altitudinal gradient ( 8 to $1886 \mathrm{~m}$ above sea level/asl). The remaining natural forests are confined to the steep sides and top of the higher hills and mountains and in protected areas, often occurring as landscapes surrounded by settlement, cultivation land, and concession areas.

\section{Procedures}

Presence records of Tapanuli orangutan

We collected data on the distribution of Pongo tapanuliensis from 2000 to 2007 throughout this historical range. A dataset of available presence records and abundance for Tapanuli orangutan compiled from the following two sources: 1) location records obtained from fieldwork and monitoring projects (direct presence and nest survey), and 2) papers, scientific research, and news. We only collected presence data since the logistical difficulty of collecting a reliable absence dataset. Geographical information for each locality was recorded in decimal degrees, based on the 1984 WGS datum. Correction of geographic coordinates from locations that are recorded incorrectly or the possibility of duplication and inconsistency is processed using Google Earth and MapLink (http://www.maplink.com/) (Ortega-Andrade et al. 2015).

Filters are essential for further analysis because the data records may contain potential errors or uncertainties. Records from two of the ways above were integrated into a dataset with brief information on the area of occupancy, and then this is compared with the actual records. Records of the species with the dataset without any hard facts, including relevant or detailed descriptions, were excluded from the analysis. All occurrences were also used to perform Ecological Niche Modeling using the Maximum Entropy algorithm (Elith et al. 2006).

\section{Environmental variable descriptors}

We used 19 environmental variables that have been shown to be suitable predictors of orangutan presence by other studies. These variables were classified into four classes: 1) physical variables such as elevation (Wich et al. 2012), slope (Wich et al. 2012), soil type (Wich et al. 2012), and distance from rivers (Arora et al. 2010); 2) resources such as distance from forest edges to the primary and secondary forest, (Wich et al. 2012; Spehar and Rayadian 2017), forest classification by altitude gradien 
(Wich et al. 2008), and vegetation productivity (Normalized Difference Vegetation Index/NDVI) (Prayogo et al. 2014); 3) anthropogencic disturbance such as distance from earthquake point, distance from settlements, roads, and cultivation ares (Wich et al. 2012; Wich et al. 2016), and land use classification (Wich et al. 2012; Wich et al. 2016); and 4) climatic variables such as annual rainfall, rainfall of the wettest month, rainfall of the driest month, annual mean temperature, maximum temperature of the warmest month, minimum temperature of the coldest month (Wich et al. 2012). The original spatial dataset included rivers and roads (OpenStreetMap 2019), digital elevation map (30 m resolution) (United States Geological Survey 2019), and land use classification layers (Ministry of Forestry 2011). Climatic variables were downloaded from the WorldClim database (worldclim.org/bioclim).

The existing 2017 land use classification layer obtained from the Ministry of Environment and Forestry contained 13 classes in our study area. The slope layer is created from the digital elevation map using the slope function in ArcGIS (Jarvis et al. 2008). From the land use classification, a forest polygon was selected and the distance from the edge of the forest to the orangutan points recorded both in the primary and secondary forest polygons was measured using the Euclidian distance (Wibisono et al. 2018). Similarly, we employed Euclidian distance to rivers, food plant sources, settlements, roads, and cultivation areas (vector) to generate the distance ( $30 \mathrm{~m}$ resolution) layers.

We generated a raster mask of $0.25 \mathrm{~km}^{2}$ cell size covering study areas to provide a baseline environment setting for further resampling processing of the background layers. We then re-sampled the Tapanuli orangutan points and all environmental variables with the application of a mask layer. For subsequent analysis, the duplication of orangutan points within a cell is removed using this procedure. We assign new values to a cell through the bilinear interpolation technique using a weighted distance average of four adjacent input cells, since the several environmental variables are sampled from finer resolution to coarser resolution. Raster Processing and Spatial Analyst tools in the software ArcGIS 10.5 were used to process all spatial dataset (ESRI, Redlands) (Wibisono et al. 2018).

\section{Batang Toru ecosystem characteristic}

Data on the physical condition of Batang Toru ecosystem and their boundaries (including aspects of resident demographics) are obtained through direct data collection and the study of reports from various parties, particularly from local governments at the Residence and Provincial levels, the Central Bureau of Statistics (BPS) and other relevant institutions.

\section{Data analysis \\ Species distribution model and environmental variable descriptors}

We modeled habitat suitability for Tapanuli orangutan using Maxent version 3.4.1. The program uses two data inputs: localities where the species has been recorded (presence-only data), and digital layers of the environmental conditions of a given area. Maxent one of the most commonly used for presence-only dataset over other techniques due to its robustness against autocorrelated environmental predictors (Phillips et al. 2006), being less affected by spatial errors (Graham et al. 2008), and little sensitive to small sample sizes (Wisz et al. 2008). Correlations between ten environmental variables were tested by Pearson correlation analysis using the Hmsc package in R software (R Development Core Team 2010). A pair of variables were removed if the correlation coefficient $\geq 0.70$ (Rahman et al. 2017; 2018; Wibisono et al. 2018). Variables used in the final dataset were elevation, slope, soil type, distance from rivers, distance from forest edges to the primary and secondary forest, forest classification by altitude gradient, NDVI, distance from earthquake points, distance from settlements, distance from roads, distance from cultivation areas, land use classification, mean precipitation, and mean temperature.

We set the soil type, forest classification by altitude gradient, NDVI, and land use classifications as categorical variables and the rest as continuous variables. We performed a Bootstrap procedure with $25 \%$ random tests, 50 replicates, and 5,000 iterations with coverage threshold $10^{-5}$. The default MaxEnt settings were maintained for all other parameters. Consistency in the importance of variables between the training and test gains was assessed with the Jackknife test (Phillips 2008; Wibisono et al. 2018). Accuracy assessment for the overall model was measured by the area under the curve (AUC) of the receiver operating characteristic (ROC) curve (Phillips et al. 2006). The AUC is the area under the ROC curve, with a value of 0.5 representing a random model, values between 0.8 and 0.9 representing models with a good fit and values over 0.9 being an excellent fit (Manel et al. 2001). We estimated the relative importance of each predictor to the Maxent model using the percent contribution and permutation importance, averaged over 50 replicates (Rahman et al. 2017).

\section{Sustainable landscape approach on Batang Toru ecosystem}

We used the implementation guidebook for a sustainable landscape approach that has been compiled by Conservation International (2018). The phases and steps of the Sustainable Landscape Approach (SLA) for the Batang Toru ecosystem have been developed with a notation regarding the Open Standards (Figure 1). In the five phases and stages of the sustainable landscape approach, the Working Group of Sustainable Management of Batang Toru Landscape (WGSM-BTL) has carried out a series of activities in the framework of identifying landscape characteristics, preparing landscape action plans and landscape finance plans. Identification of landscape characteristics, which is the phase, and the first stage in the SLA becomes the focus in proposing landscape boundaries. First, we designed the landscape of the Batang Toru ecosystem for Tapanuli orangutan conservation as "umbrella" species in their ecological role on ecosystems. Moreover, we considered the Batang Toru Landscape as a river basin linking habitats at a different area of regencies that has ecological, cultural, socio-economic, and political characteristics. The river for Batang Toru Community is 
important, not only as a driving force for the community's economy but also very closely with the culture and beliefs of the people in Batang Toru. Map of distribution and suitability of Tapanuli orangutans were overlaid by the hydrological map in three Regencies in the Batang Toru ecosystem and delineated to obtain a proposed landscape map using the software ArcGIS 10.5 (ESRI, Redlands).

\section{Identifying land use and defining its characteristics}

We used ten percentile training presence logistic threshold in the prediction model to determine the suitable landscapes for Tapanuli orangutan. The final prediction model contains pixel models with logistical probabilities greater than the threshold (Young et al. 2011; Wibisono et al. 2018). For a Critically Endangered species like Tapanuli orangutan, smaller suitable patches with confirmed evidence of Tapanuli orangutan may still be important if it supports connectivity between patches.

We assumed some protected areas that fully or partially overlapped with the predicted suitable patches as being important for Tapanuli orangutan. We used the Update tool of the ArcGIS 10.5 to updated patches with protected areas. All stand-alone protected areas are removed and combined with suitable patches into one unique polygon (Wibisono et al. 2018). Finally, we have determined how big is the Tapanuli orangutan distribution overlap with 'area for other purposes' (Areal Penggunaan Lain/APL).

\section{RESULTS AND DISCUSSION}

\section{Tapanuli orangutan distribution model}

MaxEnt analyses for 2007 conditions converged well and yielded models with good discriminatory power (AUC $=0.842)$ despite spatial filtering and background manipulation of source locality data (which tend to reduce AUC values - Kramer-Schadt et al. 2013), indicating that the models could be considered useful for projections. In west and east of Batang Toru landscape, except the north and high mountains at the southeast, we have located highpredicted suitable conditions for Tapanuli orangutan (Figure 2). Environmental parameters with the four greatest contributions to model goodness-of-fit were the distance from cultivation area $(24.7 \%)$, mean precipitation $(19,0 \%)$, NDVI (14.8\%), and distance from secondary forest edge $(13,4 \%)$. The response curves indicated that Tapanuli orangutan was more likely to occur near with distance from cultivation area and in landscapes with high NDVI and precipitation but not more than $2800 \mathrm{~mm}$ (Figure 3). Moreover, importantly, the primate experts consulted also considered the 2007 model to provide a useful representation of possible orangutan habitat (using a $10 \%$ error threshold) and particularly of the primary parts of the species range (25\% error threshold).

\section{The sustainable landscape of Batang Toru ecosystem}

The three main components in identifying landscape characteristics consist of (i) landscape goals and boundaries, (ii) stakeholder mapping, and (iii) contextual and spatial assessment. The WGSM-BTL has determined the proposed landscape boundary based on several considerations such as the distribution and habitat suitability of the Tapanuli orangutan, the physical characteristics of the ecosystem, and the demographic conditions of the population around the ecosystem. Determination of the proposed landscape is intended to realize management that supports the dynamics of regional development and community welfare in a sustainable manner by promoting environmental balance and biodiversity conservation. In terms of the actors involved, there are currently a variety of parties/stakeholders involved in the management of the Batang Toru ecosystem. With standard guidance by Fletcher et al. (2003), there are at least seven key stakeholders: the Provincial Regional People's Representative Council (DPRD) of North Sumatra, the North Sumatra Provincial Government, the Provincial Forestry Service, the Forest Management Unit (KPH) Region XI Pandan, the Natural Resources Conservation Agency (BBKSDA) of North Sumatra, as well as the District Regional People's Representative Council (DPRD) and the Regional Government (South Tapanuli, Central Tapanuli, and North Tapanuli). In addition, there are also primary stakeholders, i.e. communities around the Batang Toru ecosystem and supporting (secondary) stakeholders, i.e. NonGovernmental Organizations, Entrepreneurs (or Business Entities), as well as Universities and Research Institutions. These stakeholders have different interests and influences.

Communities living around the Batang Toru ecosystem have a high dependency on the presence of moist tropical forests and have high rainfall as a major source of water and protection from floods and erosion as is known that the Batang Toru ecosystem is the upper nine watersheds (DAS). More than half of this ecosystem is part of the largest watershed in North Sumatra. Almost all of the upper watersheds of the Batang Toru ecosystem are the last forest areas to protect the hydrological functions of the surrounding area. Therefore the existence of this ecosystem must be preserved as part of the needs and interests of the communities. In the context of Batang Toru as a river basin linking habitats at different areas of regencies/district which have ecological, cultural, socio-economic and political characteristics, we use spatial assessments in the form of hydrological functions and Batang Toru ecosystem boundaries in the unit of the region (Table 1).

\section{Tapanuli orangutan distribution model}

Applying a ten percentile threshold, only model pixels with a logistic probability of 0.45 or greater were classified as being suitable for Tapanuli orangutan. The area of suitable landscape identified for the Tapanuli orangutan population was $1.458,06 \mathrm{~km}^{2}$ [ (PA: $1.070,90 \mathrm{~km}^{2}$ or $42,98 \%$ of the Batang Toru Landscape) and non-PA (natural forest concessions and area for other uses): 387,16 $\mathrm{km}^{2}$ or $15,54 \%$ of the Batang Toru Landscape)]. Suitability habitat of Tapanuli orangutan covered $58,52 \%$ of the Batang Toru Landscape]. 
Table 1. Administrative boundaries of the Batang Toru landscape, North Sumatra, Indonesia in district/subdistrict units

\begin{tabular}{lll}
\hline District & Subdistrict & Size $\left.\mathbf{( k m}^{\mathbf{2}}\right)$ \\
\hline Padang Sidompuan & Angkola Julu & 13,56 \\
Sibolga & Hutaimbaru & 14,83 \\
South Tapanuli & Sibolga & 42 \\
& Angkola Barat & 29,69 \\
& Angkola Timur & 70,18 \\
& Arse & 64,16 \\
& Batang Toru & 299,62 \\
& Marancar & 60,02 \\
Central Tapanuli & Saipardolokhole & 48,98 \\
& Sipirok & 221,25 \\
& Badiri & 11,71 \\
& Kolang & 5,71 \\
& Lumut & 18,79 \\
& Pandan & 10,12 \\
& Pinangsori & 0,98 \\
& Sarudik & 4,36 \\
& Sibabangun & 79,57 \\
Sitahuis & 53,76 \\
& Tukka & 96,93 \\
& Adiankoting & 246,33 \\
& Garoga & 4,07 \\
& Pahaejae & 121,60 \\
& Pahaejulu & 205,90 \\
& Pangaribuan & 276,78 \\
& Purbatua & 186,88 \\
& Siatasbarita & 54,07 \\
& Simangumban & 244,61 \\
& Tarutung & 47,03 \\
\hline & &
\end{tabular}

\section{Discussion}

This study reports an extensive dataset on the Tapanuli orangutan in North Sumatra. The predictive map produced from our study not only refines maps produced from the
IUCN Tapanuli orangutan distribution assessment (Nowak et al. 2017) but represents the first to be developed from a spatially-explicit modeling process for this species. Our dataset, which is based on 536 occurrence records of the Tapanuli orangutan population, is a marked improvement on the 2015 IUCN Tapanuli orangutan assessment. Although our data derived from survey activities in 20002007, we believe that the map of distribution and habitat suitability for the Tapanuli orangutan in this paper is adequate to illustrate the current conditions since the landuse change in the study areas are low until 2019. Moreover, the robust sampling design and the variety of surveyed habitats support a more considerable extent to our result which may constitute a basic knowledge for this species conservation.

The use of presence-only dataset from the Tapanuli orangutan occurrence data used in our analysis might have certain limitations. First, data were collected using nonuniform methods from various sources (Wibisono et al. 2018). However, due to the low number of a dataset, we collect as much data as possible and filter to remove redundancy and maintain a comprehensive dataset. Second, although Maxent is less sensitive to a small number of datasets (Elith et al. 2006; Wibisono et al. 2018) and less affected by spatial errors (Graham et al. 2008), it requires that the samples (occurrence data points) be unbiased and therefore independent of the distribution of the target species (Phillips 2008). The high AUC value recorded in our model might be an artifact of the AUC statistic, which tends to be higher for species with medium-large home range sizes relative to the study area (Phillips 2008). However, the potential sampling bias here might have been overcome by our study using a relatively large dataset recorded from all possible habitat types across the Batang Toru ecosystem.

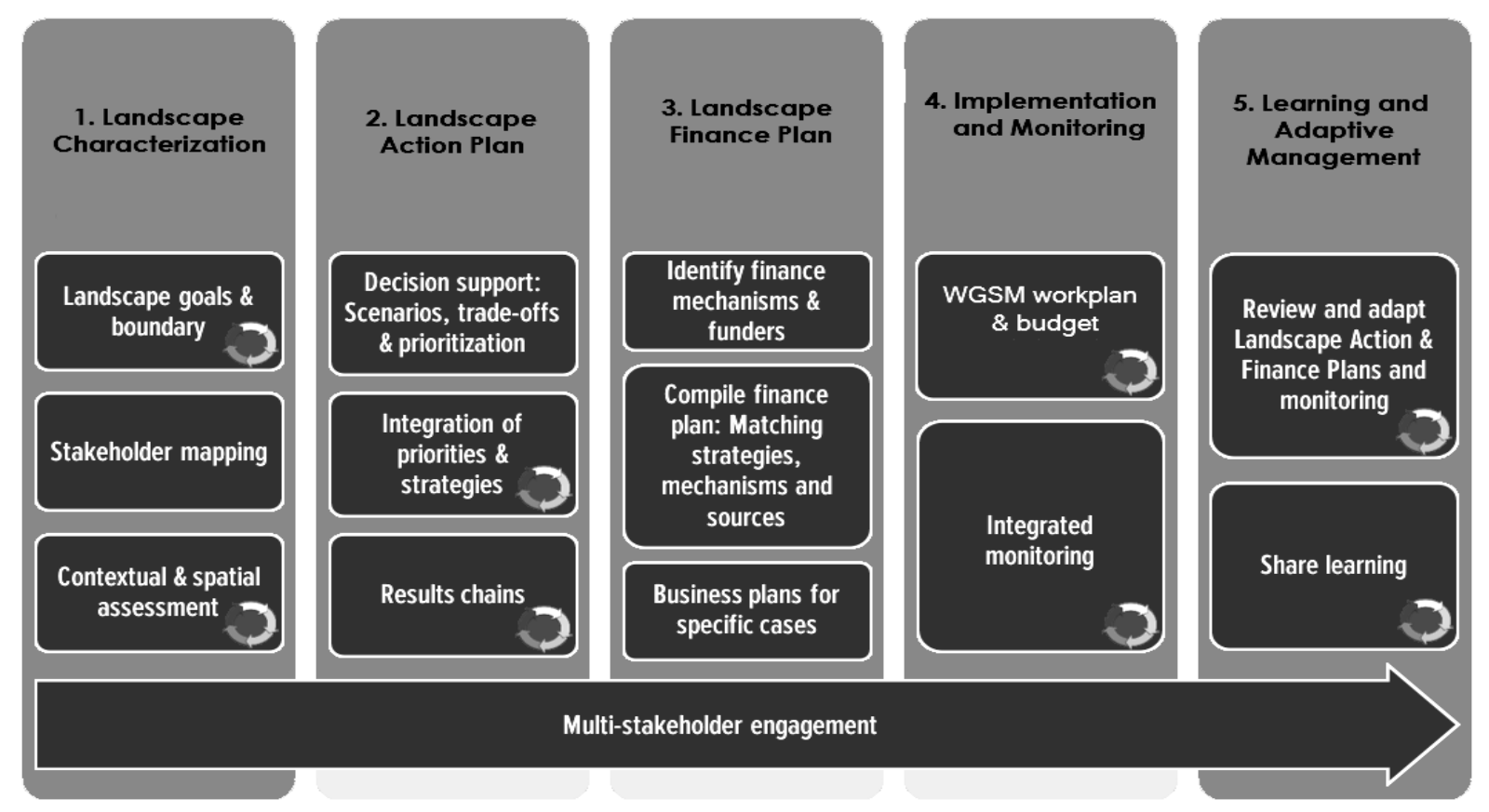

Figure 1. Phases and steps of the SLA for Batang Toru ecosystem, North Sumatra, Indonesia 


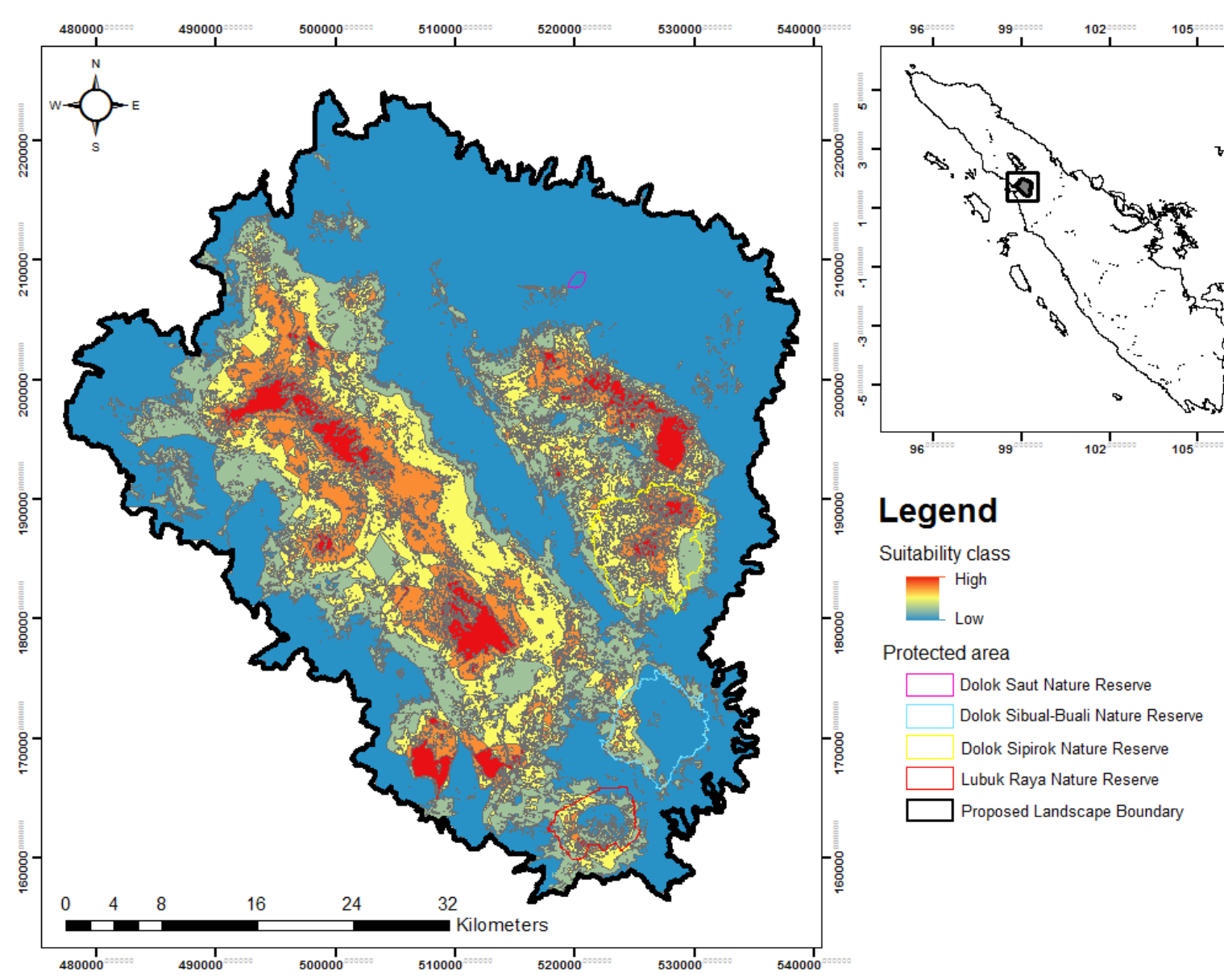

Figure 2. Probability distribution map of Tapanuli orangutan and proposed landscape boundary in the Batang Toru ecosystem, North Sumatra, Indonesia

Our study explicitly stated that Tapanali orangutan has strong preferences for secondary forests located in lowland to lower mountain forest areas of the Batang Toru ecosystem. From ca. $70 \%$ of all forest habitat types in Batang Toru ecosystem, the secondary forest was highly dominant and strongly associated with the presence of Tapanuli orangutan. They provide a high primary source of food plants for Tapanuli orangutan (Brown and Lugo 1990). Regrowth of dominant fruit tree canopies is abundant in secondary forest areas, which are conducive to frugivores' species (Brown and Lugo 1990, Moegenburg et al. 2003; Morales et al. 2013). Our result is similar to previous studies reporting that orangutan is adaptable, using a wide variety of habitats as well as feeding on a range of wild and domestic animals (Wich et al. 2012; Kuswanda 2014). The positive effects of NDVI may closely related to the presence of frugivore animals such as orangutan that are strongly dependent on the forests.

Moreover, our habitat models show also that Tapanuli orangutans are mostly concentrated far from cultivated areas and settlements, farther from human disturbances. The abundance of cultivation plants such as durian, banana, and other fruit plants associated with human-settlements might attract this species, and this interaction could create conflict with humans (Kuswanda 2014). However, a recent study in the area showed that Tapanuli orangutan tends to come closer to cultivated areas that are more attractive in the dry season (Kuswanda 2014). Tapanuli orangutans are not expected to present in areas with high annual rainfall. High rainfall can affect the distribution of orangutans through some indirect processes such as high cloud cover, which has been proven to lead to a reduction in solar radiation and hence lowering primary productivity (Boisvenue et al. 2006) and/or soil leaching can cause forests to be less productive (MacKinno et al. 1996; Marshall et al. 2009; Wich et al. 2011).

Furthermore, our results showed other variables such as elevation, slope, and distances to the river, annual mean temperature, and annual rainfall were not significant. It is likely because the variables were too small within the studied area or fall within the usual range for Tapanuli orangutan. Batang Toru ecosystem is an example of a lowland tropical rainforest with low variations in elevation (with a maximum height of 1883). Elevation was correlated negatively significant to the number of Tapanuli orangutans' presences (Kuswanda 2014). 


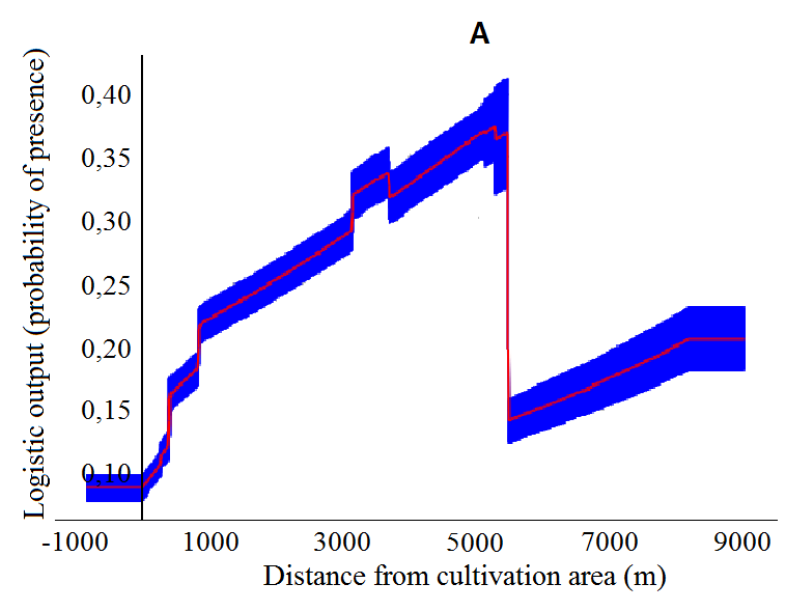

C

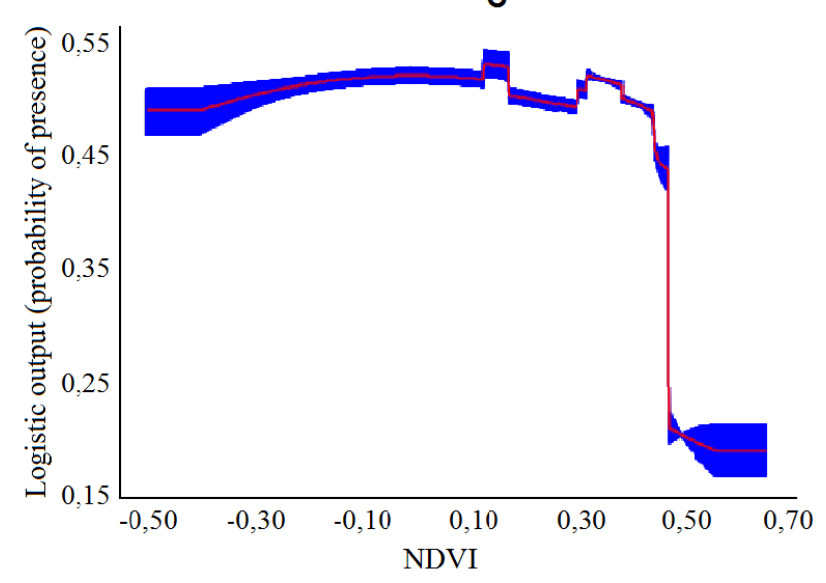

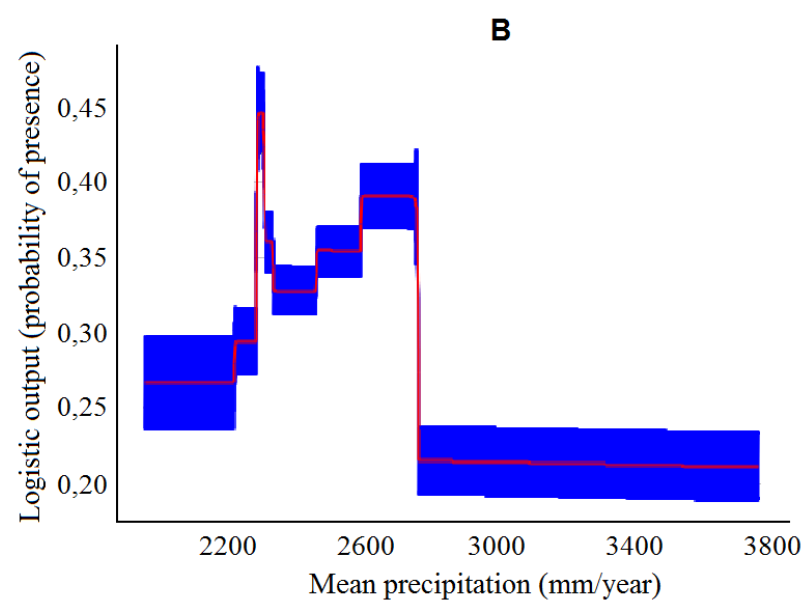

D

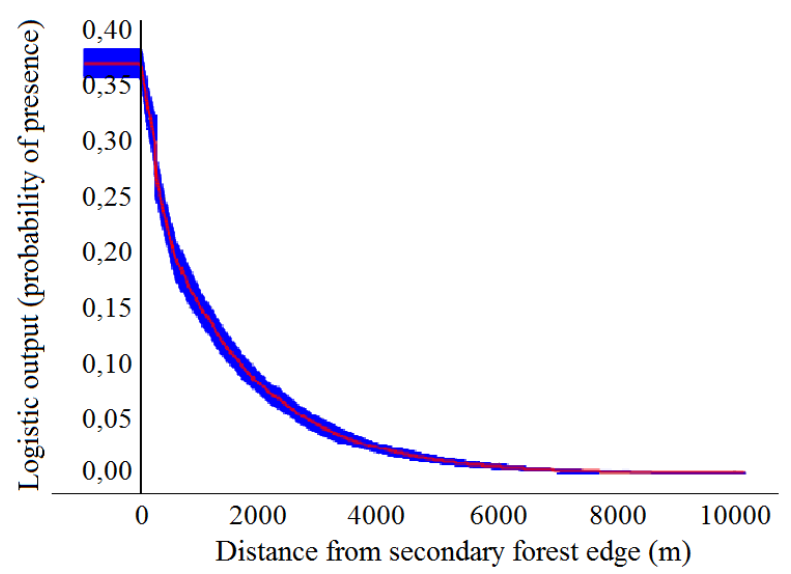

Figure 3. The response curves of the probability of Tapanuli orangutan presence as a function of environmental variables. The curves show the mean response of the 50 replicates (red) and associated one standard deviation (blue area, error bar for categorical variables)

In line with the framework of managing Batang Toru ecosystem as part of sustainable area development, the Faculty of Forestry, IPB University has initiated the "Workshop on Sustainable Management of the Batang Toru Ecosystem" that aimed to mapping the baseline data and information as a basis for compiling the agenda and the Batang Toru ecosystem management action plan. The important results of the Workshop on Management of the Batang Toru Sustainable Landscape is the establishment of the Working Group of Sustainable Management of Batang Toru Landscape (WGSM-BTL) and awakening the commitment of the three regional governments in supporting the conservation of the Batang Toru forest ecosystem and the first draft of stakeholders' action plan.

Hereinafter, to preserve the Batang Toru ecosystem in the context of conservation of the Tapanuli orangutan in harmony with the management of natural resources for the communities' welfare, the WGSM-BTL has determined the proposed landscape boundary based on three main components in identifying landscape characteristics. Batang Toru Landscape is located between $98^{\circ} 48^{\prime} 0^{\prime \prime}$ $99^{\circ} 15^{\prime} 24^{\prime \prime}$ East and 1'25'20"- $2^{\circ} 1^{\prime} 20^{\prime \prime}$ LU. This area is $2491,91 \mathrm{~km}^{2}$. Administratively, it is included in five regencies/districts, i.e., Sibolga, Padang Sidimpuan, North Tapanuli, Central Tapanuli, and South Tapanuli. Viewed from a landscape perspective, the Batang Toru ecosystem is part of the Bukit Barisan in Sumatra, which has an increasingly important role in storing carbon and in mitigating the effects of climate change. With reference to SK 579/2014, the majority of the Batang Toru ecosystem area (around $71.31 \%$ ) has been designated as a protected forest area and managed in the form of a Protection Forest Management Unit (KPHL). However, the Batang Toru ecosystem, especially in the lowlands, has experienced degradation due to land conversion for various purposes, both agricultural, plantation, and mining, that could be a threat to the existence and sustainability of the Batang Toru ecosystem. Recently, there are still illegal encroachments, and logging by urban migrants, illegal hunting, and trade also conflicts with endangered animals, as well as the use of areas for other purposes (such as mining, geothermal use, hydropower, and plantations) that will later require ecosystem recovery and conservation. The disturbance of Tapanuli orangutan particularly due to land-use change so it is very necessary to working together to protect areas that 
are prone to land-use changes such as an area for other purposes that will not be managed intensively in the future.

Collaborative management strategies are applied to develop a sustainable management system so that it could guarantee the sustainable supply of forest products (both timber and non-timber) and environmental services while maintaining biodiversity and accommodating the interests of traditional communities and development within the Batang Toru landscape ecosystem. Collaborative management can also be an essential tool in bridging synergy between parties (stakeholders) in negotiating their interests within the context of a sustainable vision of Batang Toru landscape management. This is important because at this time in the Batang Toru landscape there are already settled of extensive scale activities of resource uses by several parties such as PT SOL (in North Tapanuli), Sipan Sihapotas Hydroelectric Power Plant (in Central Tapanuli), PT Agincourt Resouces, PTPN III, and PT NSHE (in South Tapanuli); research activities by universities and NGOs, as well as local government institution and local communities which include their Hatabosi wisdom in protecting forests for the preservation of water sources.

The Indonesian Orangutan Conservation Strategy and Action Plan (SRAK) document 2019-2029 emphasizes that fragmentation due to forest conversion in the habitat of Tapanuli orangutan and poaching is a major threat to its sustainability and it is projected that sustainability for each metapopulation occurs from moderate to low. The principle that all parties must uphold in preserving Tapanuli orangutan is to maintain, stop damage and improve their habitat, prevent human-orangutan conflicts from causing the death of Tapanuli orangutan and ensure that Tapanuli orangutans can breed naturally. The implementation of this principle is very important in the Batang Toru landscape considering that many Tapanuli orangutan utilizes the area for other purposes as their habitat. Some enabling conditions to support the ongoing commitment of stakeholders to achieve the above objectives are needed, including 1) the detailed spatial planning of the Strategic Area of the Batang Toru Forest Conservation at the provincial level, which is integrated with the Spatial Details of the Strategic Area at the district and village levels, 2) the formulation of an Action Plan that can be implemented by stakeholders as an initial instrument to measure the short-term success of the conservation of Tapanuli orangutans, and 3) the realization of collaborative institutions which are the institutional basis for stakeholders to bridge the process of negotiation, facilitation, participation and conservation of Tapanuli orangutans.

\section{ACKNOWLEDGEMENTS}

We wish to thank the Aek Nauli Forestry Research and Development Agency, Indonesian Ministry of Environment and Forestry, civil society partners, and individual contributors for supporting the project.

\section{REFERENCES}

Arora N, Nater A, van Schaik CP, Willems EP, van Noordwijk MA, Goossens B, Morf N, Bastian M, Knott C, Morrogh-Bernard H, Kuze N, Kanamori T, Pamungkas J, Perwitasari-Farajallah D, Verschoor E, Warren K, Krutzen M. 2010. Effects of pleistocene glaciations and rivers on the population structure of Bornean orangutans (Pongo pygmaeus). Proc Natl Acad Sci USA 107: 21376-21381. DOI: 10.1073/pnas.1010169107.

Boisvenue C, Running SW. 2006. Impacts of climate change on natural forest productivity - evidence since the middle of the 20th century. Glob Change Biol 12: 862-882.

Branton M, and Richardson JS. 2011. Assessing the value of the umbrellaspecies concept for conservation planning with meta-analysis. Conserv Biol 25: 9-20. DOI: 10.1111/j.1523-1739.2010.01606.x.

Brown S, Lugo AE. 1990. Tropical secondary forests. J. Trop. Ecol. 6: 1 32.

Chapron G, Kaczensky P, Linnell JD, von Arx M, Huber D, Andrén H, López-Bao JV, Adamec M, Álvares F, Anders O, Balčiauskas L, Balys V, Bedő P, Bego F, Blanco JC, Breitenmoser U, Brøseth H, Bufka L, Bunikyte R, Ciucci P, Dutsov A, Engleder T, Fuxjäger C, Groff C, Holmala K, Hoxha B, Iliopoulos Y, Ionescu O, Jeremić J, Jerina K, Kluth G, Knauer F, Kojola I, Kos I, Krofel M, Kubala J, Kunovac S, Kusak J, Kutal M, Liberg O, Majić A, Männil P, Manz R, Marboutin E, Marucco F, Melovski D, Mersini K, Mertzanis Y, Mysłajek RW, Nowak S, Odden J, Ozolins J, Palomero G, Paunović M, Persson J, Potočnik H, Quenette PY, Rauer G, Reinhardt I, Rigg R, Ryser A, Salvatori V, Skrbinšek T, Stojanov A, Swenson JE, Szemethy L, Trajçe A, Tsingarska-Sedefcheva E, Váňa M, Veeroja R, Wabakken P, Wölfl M, Wölfl S, Zimmermann F, Zlatanova D, Boitani L. 2014. Recovery of large carnivores in Europe's modern human-dominated landscapes. Science 346: 1517-1519. DOI: 10.1126/science. 1257553 .

Dutta T, Sharma S, Roy PS, McRae B, DeFries R. 2016. Connecting the dots: mapping habitat connectivity for tiger in Central India. Reg. Environ Change 16 (S1): S53-S67. DOI: 10.1007/s10113-015-0877-z.

Elith J, Graham CH, Anderson RP, Dudík M, Ferrier S, Guisan A, Hijmans RJ, Huettmann F, Leathwick JR, Lehmann A, Li J, Lohmann LG, Loiselle BA, Manion G, Moritz C, Nakamura M, Nakazawa Y, Overton JMM, Peterson AT, Phillips SJ, Richardson K, SacchettiPereira R, Schapire RE, Soberón J, Williams S, Wisz MS, Zimmermann NE. 2006. Novel methods improve prediction of species' distributions from occurrence data. Ecography 29: 129-151. DOI: $10.1111 / \mathrm{j} .2006 .0906-7590.04596 . \mathrm{x}$.

Fleishman E, Murphy D, Brussard P. 2000. A new method for selection of umbrella species for conservation planning. Ecol Appl 10: 569-579. DOI: 10.1890/1051-0761 (2000)010 (0569:ANMFSO)2.0.CO;2.

Fredriksson GM, Usher G. 2017. Towards Sustainable Management of the Batang Toru Ecosystem. Yayasan Ekosistem Lestari, Medan.

Graham CH, Elith J, Hijmans RJ, Guisan A, Peterson AT, Loiselle BA, The Nceas Predicting Species Distributions Working Group. 2008. The influence of spatial errors in species occurrence data used in distribution models. J Appl Ecol 45: 239-247. DOI: 10.1111/j.13652664.2007.01408. x.

Jarvis A, Reuter HI, Nelson A, Guevara E. 2008. Hole-filled SRTM for the Globe Version 4, Available from the CGIAR-csi SRTM 90m Database. Available at: http://srtm.csi.cgiar.org.

Kashwan P. 2016. Power asymmetries and institutions: landscape conservation in Central India. Reg Environ Ch 16 (S1): S97-S109. DOI: 10.1007/s10113-015-0925-8.

Kuswanda W. 2014. Orangutan Batang Toru: Kritis di Ambang Punah. Forda Press, Bogor. [Indonesian].

MacKinnon K, Hatta G, Halim H, Mangalik A. 1996. The ecology of Kalimantan, Indonesian Borneo. Periplus Editions, Singapore.

Manel S, Williams H, Ormerod SJ. 2001. Evaluating presence-absence models in ecology: the need to account for prevalence. J Appl Ecol 38: 921-931.

Marshall AJ, Ancrenaz M, Brearley FQ, Fredriksson GM, Ghaffar N, Heydon M, Husson SJ, Leighton M, McConkey KR, MorroghBernard HC, Proctor J, van Schaik CP, Yeager CP, Wich SA. 2009. The effects of forest phenology and floristics on populations of Bornean and Sumatran orangutans. In: Wich SA, Utami Atmoko SS, Mitra Setia T, van Schaik CP (eds.). Orangutans: Geographic variation in behavioral ecology and conservation. Oxford University Press, New York. 
Ministry of Forestry. 2011. Land cover classification. https://webgis.dephut.go.id:8080/kemenhut/index.php/id/.

Moegenburg S, Levey DJ. 2003. Do frugivores respond to fruit harvest? An experimental study of short-term responses. Ecology 84 (10): 2600-2612. DOI: 10.1890/02-0063.

Morales JM, García D, Martínez D, Rodriguez-Pérez J, Herrera JM. 2013. Frugivore behavioural details matter for seed dispersal: A multispecies model for cantabrian thrushes and trees. PLoS ONE 8 (6): e65216. DOI: 10.1371/journal.pone.0065216.

Nater A, Mattle-Greminger MP, Nurcahyo A, Nowak MG, de Manuel M, Desai T, Groves C, Pybus M, Sonay TB, Roos C, Lameira AR, Wich SA, Askew J, Davila-Ross M, Fredriksson G, de Valles G, Casals F, Prado-Martinez J, Goossens B, Verschoor EJ, Warren KS, Singleton I, Marques DA, Pamungkas J, Perwitasari-Farajallah D, Rianti P, Tuuga A, Gut IG, Gut M, Orozco-terWengel P, van Schaik CP, Bertranpetit J, Anisimova M, Scally A, Marques-Bonet T, Meijaard E, Krützen M. 2017. Morphometric, behavioural, and genomic evidence for a new orangutan species. Curr Biol 27: 3487-3498. DOI: 10.1016/j.cub.2017.09.047

Nowak MG, Rienzi P, Wich SA, Meijaard E, Fredriksson G. 2017. The IUCN red list of threatened species 2017. Pongo tapanuliensis. DOI: 10.2305/IUCN.UK.2017-3.RLTS.T120588639A120588662.en.

Ortega-Andrade HM, Prieto-Torres DA, Gómez-Lora I, Lizcano DJ. 2015. Ecological and geographical analysis of the distribution of the Mountain Tapir (Tapirus pinchaque) in Ecuador: Importance of protected areas in future scenarios of global warming. PLoS ONE 10 (3): e0121137. DOI: 10.1371/journal.pone.0121137.

Phillips SJ, Anderson RP, Schapire RE. 2006. Maximum entropy modeling of species geographic distributions. Ecol Mod 190: 231259. DOI: 10.1016/j.ecolmodel.2005.03.026.

Phillips S. 2008. A brief tutorial on Maxent. ATandT Res, 1-38.

Prayogo H, Thohari AM, Solihin D, Prasetyo LB, Sugardjito. 2014. Habitat suitability modeling of Bornean orangutan (Pongo pygmaeus pygmaeus) in Betung Kerihun National Park, Danau Sentarum and corridor, West Kalimantan. Jurnal Manajemen Hutan Tropika 20: 112-120. DOI: $10.7226 / \mathrm{jtfm} .20 .2 .112$.

Rahman DA, Gonzalez G, Haryono M, Muhtarom A, Firdaus AY, Aulagnier S. 2017. Factors affecting seasonal habitat use, and predicted range of two tropical deer in Indonesian rainforest. Acta Oecologica 82: 41-51. DOI: 10.1016/j.actao.2017.05.008.

Rahman DA, Rianti P, Muhiban M, Muhtarom A, Rahmat UM, Santosa Y, Aulagnier S. 2018. Density and spatial partitioning of endangered sympatric Javan deer (Felidae) and dholes (Canidae) in a tropical forest landscape. Folia Zoologica 67: 207-219. DOI: 10.25225/fozo. v67.i3-4. a8.2018.

Rahman DA, Herliansyah R, Rianti P, Rahmat UM, Firdaus AY, Syamsudin M, 2019. Ecology and conservation of the endangered banteng (Bos javanicus) in Indonesia tropical lowland forest. Hayati J Biosci 26: 68-80. DOI: 10.4308/hjb.26.2.68.

Runge CA, Withey JC, Naugle DE, Fargione JE, Helmstedt KJ, Larsen AE, Martinuzzi S, Tack JD. 2019. Single species conservation as an umbrella for management of landscape threats. PLoS ONE 14 (1): e0209619. DOI: 10.1371/journal.pone.0209619.

Schmidt, F.H., Ferguson, J.H.A., 1951. Rainfall Types Based on Wet and Dry Ratios for Indonesia. Djawatan Meteorologi dan Geofisika, Verhandelingen, Jakarta, Indonesia.

Seddon PJ, Leech T. 2008. Conservation short cut, or long and winding road? A critique of umbrella species criteria. Oryx 42: 240-245. DOI: $10.1017 / \mathrm{S} 003060530806119 \mathrm{X}$
Spehar SN, Rayadian Y. 2017. Habitat use of Bornean orangutans (Pongo pygmaeus morio) in an industrial forestry plantation in East Kalimantan, Indonesia. Intl J Primatol 38: 358-384. DOI:10.1007/s10764-017-9959-8.

Tallis H, Kareiva P, Marvier M, Chang A. 2008. An ecosystem services framework to support both practical conservation and economic development. Proc Natl Acad Sci USA 105: 9457-9464. DOI: 10.1073/pnas.0705797105.

Turvey ST, Crees JJ, Di Fonzo MMI. 2015. Historical data as a baseline for conservation: reconstructing long-term faunal extinction dynamics in Late Imperial- modern China. Proc R Soc B: Biol Sci 282: 20151299. DOI: $10.1098 / \mathrm{rspb} .2015 .1299$.

Volken E, Brönnimann S. 2011. The thermal zones of the earth according to the duration of hot, moderate and cold periods and to the impact of heat on the organic world. Meteorologische Zeitschrift 35: 351-360. DOI:10.1127/0941-2948/2011/105.

Wibisono HT, Wahyudi HA, Wilianto E, Pinondang IMR, Primajati M, Liswanto D, Linkie M. 2018. Identifying priority conservation landscapes and actions for the Critically Endangered Javan leopard in Indonesia: Conserving the last large carnivore in Java Island. PLoS ONE 13 (6): e0198369. DOI: 10.1371/journal.pone.0198369.

Wich SA, Meijaard E, Marshall AJ, Husson S, Ancrenaz M, Lacy RC, van Schaik CP, Sugardjito J, Simorangkir T, Traylor-Holzer K, Doughty M, Supriatna J, Dennis R, Gumal M, Knott CD, Singleton I. 2008. Distribution and conservation status of the orangutan (Pongo spp.) on Borneo and Sumatra: how many remain?. Oryx 42: 329-339. DOI: 10.1017/S003060530800197X.

Wich SA, Vogel ER, Larsen MD, Fredriksson G, Leighton M, Yeager CP, Brearley FQ, van Schaik CP, Marshall AJ. 2011. Forest fruit production is higher on Sumatra than on Borneo. PLoS ONE 6: e21278. DOI: 10.1371/journal.pone.0021278.

Wich SA, Gaveau D, Abram N, Ancrenaz M, Baccini A, Brend S, Curran L, Delgado R, Erman A, Fredriksson GM, Goossens B, Husson SJ, Lackman I, Marshall AJ, Naomi A, Molidena E, Nardiyono, Nurcahyo A, Odom K, Panda A, Purnomo, Rafiastanto A, Ratnasari D, Santana AH, Sapari I, van Schaik CP, Sihite J, Spehar S, Santoso E, Suyoko A, Tiju A, Usher G, Utami-Atmoko SS, Willems EP, Meijaard E. 2012. Understanding the impacts of land-use policies on a threatened species: is there a future for the Bornean Orang-utan? PLoS ONE 7 (11): e49142. DOI: 10.1371/journal.pone.0049142.

Wich SA, Singleton I, Nowak MG, Utami-Atmoko SS, Nisam G, Mhd. Arif S, Putra RH, Ardi R, Fredriksson G, Usher G, Gaveau DLA, Kuhl HS. 2016. Land-cover changes predict steep declines for the Sumatran orangutan (Pongo abelii). Science Adv 2: e1500789. DOI: 10.1126/sciadv.1500789.

Wisz MS, Hijmans RJ, Li J, Peterson AT, Graham CH, Guisan A, NCEAS Predicting Species Distributions Working Group. 2008. Effects of sample size on the performance of species distribution models. Divers Distrib 14: 763-773. DOI: 10.1111/j.14724642.2008.00482. $x$.

Yi Y-j, Cheng X, Yang Z-F, Zhang S-H. 2006. Maxent modeling for predicting the potential distribution of endangered medicinal plant $(H$. riparia Lour) in Yunnan, China. Ecol Eng 92: 260-269. DOI: 10.1016/j.ecoleng.2016.04.010

Young N, Carter L, Evangelista PA. 2011. Maxent Model v3.3.3e Tutorial (ArcGIS v7). Colorado State University, USA 